\title{
Aprender a parar de ser humano: calar-se, não ter nome
}

\author{
Maria Filomena Molder*
}

\section{Para Scarlett Marton}

Dor e estilo, quando são canhotos,

Não os há mais vivos Herberto Helder, A faca não corta o fogo

De que malícias dispõe a inocência. Herberto Helder, Cinemas

\footnotetext{
Resumo: A partir da análise minuciosa de algumas partes do livro Aurora, este trabalho visa a mostrar a maneira pela qual Nietzsche reconfigura, a partir de novas bases, a compreensão do ser humano.

Palavras-chave: Nietzsche - Aurora - humano - vida - moral
}

Aurora é composta por cinco livros. Fiquemo-nos pelos dois últimos, que têm uma vida própria e que podem consentir ser lidos (sem largar os olhos dos outros) por si mesmos. Paulo César de Sousa, autor da tradução portuguesa publicada na Companhia das Letras em 2004 e reeditada em 2008, lembra-nos a classificação

* Professora da Universidade Nova de Lisboa, Lisboa, Portugal. E-mail: molder@gmail.com. 
temática dos aforismos, proposta pelo tradutor francês Henri Albert "responsável por numerosas versões de Nietzsche para o francês - feitas há quase cem anos e até hoje lidas -“. É esclarecedor verificar que em cada um dos três primeiros livros os vários aforismos se distribuam em famílias tematicas, ao passo que no que se refere aos dois últimos cada um versa sobre um assunto, a saber: Livro IV. Aforismos 208-422 (M/A KSA 3.199-257): coisas humanas e Livro V. Aforismos 423-575 (M/A KSA 3.259-331): o universo do pensador" ". Consideraremos estes resumos talvez insuperáveis.

2

Seguindo as instruções de leitura fornecidas pelo próprio Nietzsche no $\$ 454$ (KSA 3.274-5) - "Digressão. - Aurora não é para ser lida rapidamente e em voz alta, mas aberto com frequência, sobretudo ao passear ou viajar, enfiando e retirando a cabeça - e surpreender que o habitual à nossa volta acabou de cessar" -, tirámos as consequências.

Apresentamos uma leitura selvagem, repetida, digressante, como quem passeia ou viaja pelas suas páginas, o que ainda não acabou de ser feito, o que não acabará. Enfiar e retirar a cabeça: eis uma das liberdades que não nos é permitido ceder em Aurora. Umas vezes ficamos presos nos seus liames, outras perdidos nos labirintos, atraídos pela noite, cegos pela escuridão, feridos nas falésias, batidos pelo mar, sempre e sempre atraídos, e sempre e sempre tentando não perder o fôlego, temendo sair desfigurados, como os que se aventuravam pela gruta de Trophius: "o habitual à nossa volta acabou de cessar".

1 Apud SOUZA, P.C. "Posfácio" a Aurora, P.312 (Trad. Paulo César de Sousa. Companhia das Letras: São Paulo, 2008. 
Se enfiarmos a cabeça no §1 (M/A, KSA 3.11) do Prólogo ouvimos dizer que neste livro há um ser subterrâneo a trabalhar, um sapador, um mineiro, empenhado num trabalho de profundezas. Incapaz de "trair o excesso de aflição que acompanha qualquer privação prolongada de luz e ar". Trabalho sombrio. No §2 (M/A, KSA 3.11-2) este Prólogo "tardio" é-nos apresentado como um "poderia ter sido", a saber, "um último adeus, uma oração fúnebre", pois "perigo, acaso, maldade e mau tempo" poderiam "naquele tempo" ter feito soçobrar o autor, uma vez que ele fez estremecer o mundo nos seus sustentáculos - isto é, a moral, a "Circe dos filósofos", cujos poderes de atracção e de persuasão são temíveis, e agora já enfiámos a cabeça no 33 (M/A, KSA 3.13-5). Fazer estremecer o mundo é uma especialidade de Poseidon (o que não é alheio ao mar de Génova). Mas ainda há um outro deus grego mestre nesta mesma especialidade e que é um baptismo nietzschiano, Dioniso ${ }^{2}$, também amigo do mar e de tudo quanto cresce por movimentos meândricos (a hera, a vinha). Pergunta Nietzsche no $\$ 4$ (M/A, KSA 3.15-7): "o que sucede em nós" (sendo nós ele e o seu livro) e responde, passando pela bela palavra inventada de "imoralismo": "a auto-supressão da moral".

Retiramos a cabeça e divagamos, olhamos para uma pequena lagartixa que acaba de perder a sua cauda. Mas imediatamente, talvez incitados por essa memória da infância, enfiamos a cabeça no último, o §5, deste Prólogo tardio (de 1886, Aurora data de 1881), e já não nos sentimos arrebatados, desce sobre nós uma calma, uma lentidão maldosa, trazida pelas mãos de Nietzsche enquanto se volta

2 "Enquanto filólogo e homem de palavras, baptizei-a [a contra-doutrina e a contra-avaliação anti-cristã que julgará a moral a partir da aparência, da arte, da ilusão, da necessidade de perspectivismo e de erro], não sem alguma liberdade própria - pois quem saberia o nome do Anti-Cristo? - com o nome de um deus grego: chamei-lhe dionisíaco" (final "Versuch einer Selbstkritik", 1886, §5). Tradução e sublinhados meus. Voltaremos ao baptismo. 
para trás: "porque deveríamos dizer tão alto e com tal fervor aquilo que somos, que queremos e não queremos?" Pede-se discrição, para "que o mundo não nos ouça". Pede-se paciência, precaução, demora, "dar-se tempo" no meio das querelas da pressa, fala-se em lento trabalho de ourives (há muito brilho, fulgor, muito ouro, nas minas destes dois livros de Aurora) que é próprio do filólogo, e o seu resultado não é um resultado, isto é, não se trata de um livro terminado "em meio a uma época de 'trabalho', isto é, "de pressa, de indecorosa e suada sofreguidão". Tomar o seu tempo (é como as pequenas doses homeopáticas para mudar um longo hábito, uma crença aprendida e venerada, cf. M/A 534, KSA 3.305, As pequenas doses), distanciar-se, tornar-se silencioso, tornar-se lento, e pedir lentidão: repetir, repetir, repetir a leitura "com segundas intenções, com as portas abertas, com dedos e olhos delicados".

E dirigindo-se polidamente (a quarta virtude, a exercitar "sempre", na verdade, como se verá adiante, um elemento da máscara em Nietzsche) a nós, que ainda temos a cabeça enfiada, escreve: "Meus pacientes amigos, este livro deseja apenas leitores e filólogos perfeitos: aprendam a ler-me bem!" Desenfiamos a cabeça, mimando o poeta do Confiteor de l'artiste de Baudelaire, que esgrimindo com a beleza se dá por vencido e cai gritando de susto (mas só assim o poema pode nascer). Não é esse o nosso caso, mas nalgum ponto o tocamos, pois quem serão esses leitores perfeitos senão os que forem vencidos, perfeitos porque foram vencidos, porque não conseguem dar conta do recado, porque deixam cair o que estava no regaço, os que, depois de terem enfiado e desenfiado vezes sem conta a cabeça, fecham as portas, interrompem a viagem e se perdem na velocidade tão pouco filológica. Perfeitos, não sei.

Porém este Prólogo tem de ser equilibrado com as palavras de Ecce homo sobre Aurora, pois o mar genovês, ainda tão grego, é o elemento em que ele se engendra e do qual recebe uma doçura inflexível: "ele [...] está deitado ao sol, redondo, feliz, semelhante a um animal marinho que toma um banho de sol entre rochedos. Afinal, era eu próprio esse animal marinho: quase cada frase do 
livro foi concebida, foi apanhada naquela confusão de rochedos próxima de Génova, onde eu estava sozinho e até tinha intimidade com o mar" (EH/EH, Aurora, KSA 329-332).

É ainda em Ecce homo que Nietzsche nos fala desses momentos dolorosos e doentios em que conhece uma felicidade suprema: "basta observar a Aurora ou, por exemplo, $O$ Viandante e a sua sombra, para compreender o que foi «esse regresso a mim»: foi mesmo uma suprema forma de convalescença" (isto quando está a falar de Coisas humanos, demasiado humanas ${ }^{3}$, p.190). E mais adiante desenha num arabesco único o coração inflamado de $A u$ rora: "Com Aurora empreendo, em primeiro lugar, a luta contra a moral da renúncia a si próprio".

Tantas são as vezes, em particular nas partes a que mais nos dedicamos, os Livros IV e V (que ressoam também no Prológo), em que se repetem as imagens da profundeza e da escuridão, do trabalho do mineiro e do sapador, da privação da luz e do ar (trabalho e experiência tão arcaicos, lembre-se a Epopeia de Gilgames - o primeiro poema, cuja versão antiga é anterior um milhar de anos às Epopeias homéricas -, a história do homem que não queria

3 Paolo d'Iorio em Le voyage de Nietzsche à Sorrento esclarece de maneira irrefutável porque devemos traduzir Menschliches, Allzumenschliches por Coisas humanas, demasiado humanas. Tradução cujas bases são temáticas: “[...] deve haver uma maneira de dar valor às coisas humanas [...] Nietzsche toma posição contra Platão, contra o pessimismo e propõe os esboços de uma outra visão", p. 196; e também linguísticas: "Esta interpretação reforça as justas observações de Charles Adler no que respeita à tradução do título Menschliches, Allzumenschliches nas línguas neolatinas: «Não ignoro que tradutores conhecidos, e cegamente depois deles a totalidade dos críticos franceses, traduzem Menschliches, Allzumenschliches, por Humano, demasiado humano. Eles traduzem como se Nietzsche tivesse posto Menschlich, Allzumenschlich. No entanto Nietzsche acrescentou uma desinência, e portanto é preciso traduzi-la. Menschliches, Allzumenschliches são substantivos de forma partitiva. Menschlich, Allzumenschlich seriam adjectivos, com uma função de atributo. Confundir estas duas funções, é um contra-senso. Nietzsche, que pensava frequentemente em latim, poderia ter intitulado o seu livro Humana, nimis humana. Não temos o direito de o traduzir como se ele tivesse dito Humanum, nimis humanum», p.196, nota 44 (tradução minha). Referência da obra de ANDLER, C. Nietzsche. Sa vie et sa pensée. Paris: Galllimard, 1958, 3v. 
morrer $^{4}$ ) e, ao mesmo tempo, as da conversão em ouro, do brilho do ouro que torna tudo incomestível, do fogo e das cinzas, do fulgor.

Talvez ele queira conhecer as longas trevas que só lhe pertencem a ele, "o seu elemento incompreensível, secreto, enigmático" e para quê? Para, em troca, obter a sua própria manhã, a sua própria redenção, a sua própria aurora. Que procura ele nas profundezas tão fundas? Um dia ele há-de dizê-lo "apesar da sua aparência de Trophius", "uma vez que se torne homem de novo". Isso também lhe ensinam o mar e a noite. "Desaprende-se inteiramente o silêncio quando se foi - tanto tempo como ele - sempre um sozinho". A desaprendizagem do silêncio, própria de um sozinho será um aguilhão, incita-o a falar. Mas é preciso corrigi-la com as instruções do mar Vamos ter com ele.

Dentro do grande silêncio - Aqui está o mar, aqui podemos esquecer a cidade. Os seus sinos ainda tocam neste momento a Ave Maria - esse ruído sombrio e tolo, porém doce, no cruzamento do dia com a noite -, mas apenas por mais um instante! Agora tudo se cala! O mar se estende pálido e cintilante, não pode falar. O céu traz o seu eterno e silencioso espectáculo vespertino em cores rubras, verdes e amarelas, não pode falar. As pequenas falésias e recifes que entram no mar, como que buscando o lugar mais solitário, nenhum deles pode falar. Essa mudez enorme, que subitamente nos toma, é bela e aterradora, diante dela o coração se inflama. - Oh, a hipocrisia

4 A fim de obter o que procura, a imortalidade, Gilgames realiza uma viagem na qual passa por uma série de provas, a primeira das quais, que se dá logo no início da viagem, consiste em atravessar um subterrâneo que ele percorre dias e dias sem nunca ver a luz do dia. Num certo momento em que o desespero e o terror o invadem, ele solta um grito tamanho que se vê fora do subterrâneo, perto de uma estalagem. Fiquemo-nos por aqui. Cf. L'Epopée de Gilgames. Le grand homme qui ne voulait pas mourir. Traduzido do acadiano e apresentado por Jean Bottéro, L'aube des Peuples, nrf Gallimard, Paris, 1992. 
dessa muda beleza! Como poderia falar bem, e mal também, se apenas quisesse! Sua língua atada e a sofredora ventura em seu rosto são uma perfídia, querem zombar da nossa simpatia! - Pois seja! Não me envergonho de ser a zombaria de tais poderes. Mas tenho compaixão de você por sua malícia! - Ah, faz-se ainda mais silêncio, e novamente se inflama o meu coração: apavora-se ante uma nova verdade, também não pode falar, ele próprio zomba justamente, se a boca exclama algo nessa beleza, ele próprio desfruta sua doce maldade em silenciar. A fala, e até o pensamento, tornam-se para mim odiosos: não escuto o erro, a ilusão, o espírito delirante a rir por trás de cada palavra? Não tenho que zombar de minha compaixão? Zombar da minha zombaria? - Oh, mar! Oh, noite! Vocês são maus instrutores! Ensinam o ser humano a parar de ser humano! Deve ele entregar-se a vocês? Deve tornar-se, como são agora, pálido, brilhante, mudo, imenso, repousando em si mesmo? Elevado sobre si mesmo? (M/A 423, KSA 3.259-60).

É com este aforismo que se inicia o Livro V: a natureza, o mar, faz esquecer a cidade. Ainda soa "o ruído sombrio e tolo", embora "doce" dos sinos, os marcadores da passagem dia para a noite. Mal acabam de lançar o seu aviso e já se afunda o dia e já tudo se cala. "Agora tudo se cala! $O$ mar ... não pode falar. $O$ céu ... não pode falar. As pequenas falésias e recifes ...nenhum deles pode falar". E sem poder conter-se diante de todos estes que não podem falar o coração dele inflama-se, diante desta "mudez enorme" que o agarra, que toma conta dele, "bela e aterradora". E agora começa o que nos obriga a enfiar e desenfiar a cabeça numa escalada perigosa, abissal: a descoberta da "hipocrisia dessa muda beleza". Hipocrisia, jogo daquele ser do qual Nietzsche mais próximo está sempre, e desde $O$ Nascimento da Tragédia, o actor, o dissimulador, o que transporta uma máscara, o gesto heróico que estamos sempre a surpreender nas suas palavras, aqui aplicando-se ao mar, pois "se apenas quisesse poderia falar bem, e mal também".

Pequeno intervalo sobre a máscara: conhecemos muitas diatribes de Nietzsche contra o histrião, sobretudo nas suas páginas 
mais críticas da arte, e da música de Wagner em particular. Mas tal não invalida - bem pelo contrário - que a atenção apaixonada pela figura e pelo destino do actor seja tão intensa. $\mathrm{O}$ recurso à máscara em Nietzsche procede também do conhecimento desta forma de possessão e êxtase. Como pensador, Nietzsche não poderia existir sem máscara, sobretudo a partir do momento em que luta "contra a moral da renúncia a si próprio", o que inclui a polidez como óleo que lubrifica a solidão e a sua relação com os outros ${ }^{5}$. As palavras que ele dirige ao mar e à noite são, ainda antes de a nomear, uma segregação da máscara. No $§ 40$ de Para além do bem e do mal Nietzsche já mostra sua maestria quanto ao saber e aos usos da máscara própria de um

dissimulador que, por instinto, precisa do discurso para se calar e manter silencioso e que inventa todos os pretextos para não comunicar, quer e exige que uma máscara ocupe o seu lugar, no coração e na cabeça do seus amigos [...] Cada espírito profundo necessita de uma máscara, graças à interpretação permanentemente falsa, quer dizer, superficial, de cada palavra sua, de cada um dos seus passos, de cada sinal de vida (JGB/BM 40, KSA 5.57-8).

Acabado o intervalo.

Desenfiamos a cabeça por estranheza, pela suposição de um mar que, se quisesse, poderia falar, e bem e mal conforme, quase perto de uma antropomorfização comum! Vá, não te apresses. Continua, volta a enfiar a cabeça, desiste de qualquer interpretação, segue apenas os sons que lês, as figuras que desenham, os efeitos das forças que despertam. Continuemos. O mar, as falésias, os recifes, a noite, têm a língua atada apenas por troça, "a sofredora ventura

5 Não convém que haja equivalência igualitária na polidez entre dois, é preciso que haja um desnível, que se produzam pequenas desigualdades, senão corre-se o risco de o mecanismo ficar "alagado em óleo". Cf. (M/A 392, KSA 3.251). 
no seu rosto é só perfídia". Sofredora ventura, se o mar começasse a falar que diria? Seguramente se queixaria de nós ${ }^{6}$, mas mesmo a queixa é uma perfídia, pois nós seremos sangrados nas suas águas. Só que Nietzsche aceita a zombaria, não se envergonha por ser troçado por forças tamanhas e, ao mesmo tempo, não resistindo, obedecendo às instruções da zombaria e da perfídia, sente compaixão pelo mar, sente compaixão pela sua malícia. E de novo "se inflama o meu coração": é que ele "também não pode falar", também o coração dele conhece essa perfídia da zombaria e goza com "a doce maldade em silenciar". E subitamente começamos a vislumbrar o caminho por onde Nietzsche nos leva: não escutamos nós atrás de qualquer palavra "o erro, a ilusão, o espírito delirante a rir"? E seguem-se mais duas perguntas (e outras mais se seguirão), respostas supremas às instruções do mar e da noite: "Não tenho que zombar da minha compaixão? Zombar da minha zombaria? ${ }^{7}$ Finalmente numa apoteose de dor e alegria ouve-se um apelo, um grito, uma descoberta: "- Oh, mar! Oh, noite! Vocês são maus instrutores! Ensinam o ser humano a parar de ser humano!".

Parar de ser humano: eis o ensinamento terrível, pérfido, o ensinamento de que Nietzsche estava à espera e que nenhum ser humano lhe poderia ter soprado ao ouvido. Os instrutores, os maus instrutores, são seres calados, seres que não argumentam, forças que se medem com ele trocistas, zombando, ele que é um pequeno animal marinho banhado pelas águas do mar. E o coração dele sente-se parte do elemento marítimo e da sua noite, calados, silenciosos, inflama-se e zomba por se ter inflamado, ao descobrir que também ele se deverá calar, conhecendo como conhece o confusão ilusória, hilariante, que se abriga atrás de cada palavra.

6 Como diz Antonioni sobre o Sol: ele deve odiar-nos pelo tanto que sabemos sobre ele. Cf. ANTONIONI, M. Fare un film è per me vivere. Scritti sul cinema. Veneza: Marsilio Editore, 1994.

7 Um exemplo de tal desdobramento humorístico encontramo-lo na relação entre enrouquecer e ser refutado no $\$ 232$ - De uma discussão. 
Costuma considerar-se Aurora uma obra do período intermédio, período médio. Consideração que tem a sua utilidade, mas que igualmente nos pode impedir de ver que não há períodos médios, baixos e altos e por aí adiante no caso de Nietzsche (e de tantos outros), o nosso engenho é que sepulta os autores nesses jazigos. Há, antes, vibração extrema de estar vivo, amor apaixonado pelo conhecimento, veneração pelos mestres, e todos os júbilos e desastres que uns e outros arrastam consigo. Em Aurora vemos um prelúdio à exigência «Deves tornar-te no homem que és», coisa que a consciência lhe diz na Gaia Ciência (Livro III, §27), prelúdio alimentado pelo género de existência preliminar ou retardatária, que é própria do tempo que segue às Coisas humanas, demasiado humanas, no qual ele está a tirar e a desenrolar as consequências do projecto íntimo de se tornar um espírito livre, preparando para se tornar naquilo que é$^{8}$. Este prelúdio não corresponde a uma fase intermediária, tem uma identidade própria que procede do ensinamento dos maus instrutores: "parar de ser humano". E nas perguntas finais do mesmo aforismo encontramos já as respostas que abrem caminho para a visão do sobre-humano: "Deve ele entregar-se a vocês? Deve tornar-se, como são agora, pálido, brilhante, mudo, imenso, repousando em si mesmo? Elevado sobre si mesmo?". Aceitar o ensinamento que não é um doutrina, mas a fonte cósmica da moral que consiste em não renunciar a si próprio - dos maus instrutores, desdobra-se em entregar-se a eles, fazer-se tão pálido, brilhante, mudo imenso, como eles, quer dizer, repousar em si próprio. Finalmente, em elevar-se sobre si mesmo, em vencer-se, superar-se a si próprio, prenhe de uma visão que ainda não tem nome, mas talvez um dia tenha, desmedida a que no de $A$ gaia ciência ele chama originalidade:

8É difícil não estabelecer relação - mais contrastante não poderia ser - com aquilo que Mefistófeles diz a Fausto: Du bist am Ende - was du bist/.../ Du bleibst doch immer, was du bist, HA 3, versos 1806 e 1809. 
O que é a originalidade? É ver algo que ainda não tem nome, que ainda não pode ser nomeado, conquanto esteja à vista de todos? Sendo os homens como habitualmente são, só o nome permite que uma coisa se torne visível para eles. Na maior parte das vezes têm sido também os que dão o nome às coisas (FW/GC 261, KSA 3. 517).

$\mathrm{O}$ aspecto mais decisivo na originalidade é conseguir ver o que está à vista de todos mas ninguém se atreve a ver. Sublinhe-se o ponto de interrogação, que mostra bem não se tratar de uma doutrina. Por acréscimo talvez venha o nome, o baptismo (por isso ele diz na "Selbstkritik" que é "um discípulo de um deus ainda desconhecido", mesmo que lhe chame Dioniso, o deus deconhecido ainda não recebeu nome). Como Goethe, Nietzsche também conhece "o perigo de matar a existência viva do mundo com a palavra" ". É nessa visão sem nome que se incrustam os experimentos da solidão, a transmutação alquímica, ouro e fome, a diferença entre eu e eu, a escolha entre a vida servir a verdade ou a verdade servir a vida que serão objecto da nossa atenção. Mas antes de nos dedicarmos a eles, acrescentemos ainda que aquelas perguntas finais do $\$ 423$ (M/A 423, KSA 3.259-60) de Aurora são outros tantos ou ... ou, nunca disjuntivos, mas também resistindo a serem alternativos, que atravessam inquietos, inseparáveis, devido à potência das forças magnética que os agarram, muitos dos aforismos, deflagrando nos gritos no final $\$ 575$ sob forma de interrogação:

Queremos transpor o mar? Para onde nos arrasta essa poderosa avidez, que para nós vale mais do que qualquer outro desejo? Por que justamente nessa direção, para ali onde até hoje os sóis da humanidade se puseram, desapareceram? Dirão as pessoas, algum dia, que também nós,

9 Die Farbenlehre, §754, HA 13, p.492. Não é igualmente conveniente ignorar que os poderes das palavras provêm de empréstimos nossos e, portanto, se nos desfizermos deles, corremos o risco de ficarmos ao mesmo tempo mais ricos e mais avaros. Cf. $\$ 210$ intitulado " $O$ 'em si"” (M/A 210, KSA 3.507). 
rumando para o Ocidente, esperávamos alcançar as Índias - mas que nosso destino era naufragar no infinito? Ou então, meus irmãos? Ou? (M/A 575, KSA 3.331).

"Ou então, meus irmãos? Ou?": nem disjunção nem alternativa. Aliás, em Ecce homo ele lembra: que Aurora é a única obra que termina com um "Ou ...? Ou...?". Naufragar no infinito, não, não é para isso que se aparelha o barco em Aurora, mas para a viagem que obedece a todos os desvios da agulha magnética. E seguindo os sulcos deste estilo canhoto - inseparável da dor canhota - regressemos à originalidade nietzschiana, a uma das suas pedras-de-toque mais imaginativas e pungentes da originalidade, tal como aparece num outro aforismo da Gaia Ciência:

O meu cão. Dei um nome à minha dor e chamei-lhe "cão" - ela é tão fiel, tão importuna e desavergonhada, tão divertida, tão esperta como qualquer cão - e eu posso dominá-la e descarregar nela as minhas más disposições como outros fazem com o seus cães, criados e mulheres (M/A 312, KSA 3.547-8).

Primeiro trata-se de ver aquilo que habitualmente não é visto porque ainda não tem nome, Nietzsche conhece-a bem, todos lhe chamam dor - e costumam virar-lhe as costas - ele, que a conhece bem, descobriu que era um animal domesticado, doméstico, deu-lhe um nome: "cão", aquele animal que não se defende do seu dono, que não o ataca, mas o segue "fiel, importuno e desavergonhado, divertido, esperto". Na verdade, a dor é importuna e desavergonhada porque é fiel, não o larga, segue-o por todo o lado, não quer saber de mais nada, inadaptada a qualquer outra vizinhança, acompanha o dono, sem exigências, amena e esperta, farejando o seu caminho, antecipando-o. Temos aqui mais um efeito da zombaria que os maus instrutores lhe fizeram ouvir, com que o adestraram: ter chamado "cão" à sua dor é um modo de zombar dela - e como levá-la mais a sério? -, zombaria que é inseparável do coração inflamado. 
"Um amigo de enigmas" é assim que Nietzsche se apresenta no Versuch einer Selbstkritik, aquele que redigiu $O$ Nascimento da Tragédia. Nele o enigma ressurge intacto, como caso de vida ou de morte, a uma vez anseio e consequência do querer beber da sua própria cisterna. Quer dizer, ele tornou-se um enigma para si próprio e é isso que desde Coisas humanas demasiado humanas importa decifrar e que tem a ver, como veremos, com a diferença entre eu e eu. Em Aurora, sobretudo nos livros IV e V, deparamos com um manancial de enigmas (embora sem trama narrativa, percebemos neles indícios do Zaratustra) - apontando de novo este aspecto estilístico - que os vários pontos de interrogação com que certos aforismos terminam, que os diálogos entre A e B, que os ou ... ou, acentuam, assinalando a multiplicidade, a abundância, dos pontos de vista, onde se incluem e misturam compaixão e zombaria.

Nietzsche está a braços com enigmas vivos, nos quais está enredado (melhor, ele é todos os protagonistas). Quer dizer, que tenham nascido dele não diminui em nada a perplexidade, o paradoxo, o imprevisível, numa situação kat'exochén de "já não" e do "ainda não". Coisa que aparece designada como "interregno moral":

Interregno moral. - Quem estaria agora em condições de descrever o que substituirá, um dia, os sentimentos e juízos morais? - ainda que possamos ver claramente que todos os seus fundamentos se acham defeituosos e que seu edifício não permite reparação: seu carácter obrigatório diminuirá dia após dia, enquanto não diminuir o carácter obrigatório da razão! Construir novamente as leis da vida e do agir para essa tarefa nossas ciências da fisiologia, da medicina, da sociedade e da solidão, não se acham ainda suficientemente seguras de si: e somente delas poderemos extrair as pedras fundamentais para novos ideais (senão os próprios ideais mesmos.) De modo que levamos uma existência provisória ou póstuma conforme o talento e o gosto de cada um e o melhor a fazer nesse interregno será tornamo-nos reges para nós 
próprios e fundar pequenos Estados experimentais: Nós somos experimentos. Sejamo-lo de bom grado (M/A 453, KSA 3.274).

É de sublinhar que esta existência provisória ou póstuma (ou... ou) é forjadora de poder, é fundadora de "pequenos Estados experimentais". Nietzsche, ele e a sua solidão: "Nós somos experimentos", e o coração inflama-se-lhe de entusiasmo, pois que a existência seja provisória ou preliminar, póstuma ou retardatária, nada tem a ver com a enganadora perspectiva de ter uma outra vida para viver, como diz o sofista Estobeu: "Não se pode voltar a jogar a vida como um dado que tornamos a lançar".

Aurora é um laboratório, uma cozinha subterrânea - é o que vemos na sua apreciação de que as nossas ciências acham-se ainda em estado inseguro para "construir novamente as leis da vida e do agir", isto porque a última ciência, a ciência da solidão, ainda não passou por todas as suas provas, ainda não deu todas as suas provas, ele ainda há pouco acabou de ouvir as instruções pérfidas do mar e da noite. A solidão é uma disciplina fisiológica de limpeza ${ }^{10}$ que leva o seu tempo, trabalho delicado de ourivesaria. Por isso, embora, a sequência das ciências enumeradas por Nietzsche nos deixe perplexos a uma leitura desprevenida, elas enleiam-se umas nas outras por vínculos cuja energia magnética a ciência da solidão emite e rege. Um contra-exemplo da ciência da solidão é-nos fornecida pelo próprio Nietzsche no $\$ 440$ : "Renunciar ao mundo sem conhecê-lo, como uma freira - isso resulta numa estéril e talvez triste solidão". Num aforismo anterior mostra-se incandescente, precisa, inigualável, o que poderá ser uma solidão que passou pelas suas provas, isto é, as consequências de não renunciar a si próprio, através de uma visão profética que anuncia um nome, vontade de potência, mas não o diz:

10 Cf. COLLI, G. Dopo Nietzsche. Milão: 4․ Ed. Milão: Adelphi Edzioni, 1988, p.112. 
Privilégios. - Quem realmente possui a si mesmo, isto é, conquistou definitivamente a si, vê doravante como privilégio próprio castigar-se, perdoar-se, compadecer-se de si mesmo: ele não precisa concedê-lo a ninguém, mas pode livremente passá-lo às mãos de outro, de um amigo, por exemplo - mas sabe que assim confere um direito, e que direitos podem ser conferidos apenas desde que se possua poder (M/A 437, KSA 3. 268).

E, no entanto, mais atrás, no §315, tínhamo-nos deparamos com um passo que vence estes privilégios, numa espécie de superação da vontade de potência, no momento em que a renúncia ao seu direito, o deixar cair algo da sua posse, provoca alegria, é sinal de riqueza, da qual a generosidade faz parte: eis a doçura do coração. Aqui, neste momento, compreendemos que não é de ânimo leve que Nietzsche nos pede que enfiemos e retiremos a cabeça em Aurora, passando os olhos pelos aforismos enquanto passeamos, enquanto viajamos.

Demoremo-nos nos privilégios. Como é que se chega a eles? Através da independência, que Nietzsche qualifica de "'liberdade de expressão' na sua dose mais fraca" que cabe a alguém, ansioso por domínio, e que tendo procurado longamente o que pudesse dominar, descobriu que só havia ele próprio - uma particular forma de renúncia (veja-se M/A 242, KSA 3.257) ${ }^{11}$. Inseparável desta "'liberdade de expressão' na sua dose mais fraca", acrescente-se a coragem do sábio, "aquele que mais verá a si mesmo e a existência abaixo de si”, a que também se pode chamar uma extravagante generosidade. O que poderá querer dizer isto? Fechamos Aurora no $\$ 551$ e voltamos a casa, à espera do próximo passeio. A palavra futuro não nos larga. Palavra a que convém como uma luva o

11 Mais uma vez surpreendemos uma afinidade com Goethe: "Procurem em vós e tudo encontrareis e hão-de alegrar-se quando lá fora existir uma natureza ou como lhe queiram chamar, que diz sim e ámen a tudo o que descobrirem em vós". Máxima 511, HA 12, p.36 (tradução minha). O que nada tem a ver com a descida à caverna iluminada artificialmente da subjectividade ou da falsa introspecção. 
Ou...? Ou...? final. Abrimos as portas e voltamos a enfiar a cabeça: aquela coragem é a daqueles que nos levariam para longe, para as virtudes futuras - serão elas: a lealdade para connosco próprios e todos quantos contam como amigos; a valentia: contra o inimigo; a magnanimidade: para com o vencido; a polidez, a cortesia: sempre, as quatro virtudes cardinais, enunciadas no §556, serão elas, nascidas do ver-se a si mesmo e a existência em todo o redor, aquelas que nos encaminham para além do que temos? ${ }^{12} \mathrm{Ou}$ são "virtudes que jamais existirão na Terra, embora já pudesse haver em algum lado do mundo - de constelações purpúreas e grandes Vias Lácteas do belo! Onde estão vocês, astrônomos do ideal?". Nesse momento vem ter connosco em nosso auxílio a imagem da aurora, aquele anseio de Nietzsche de conhecer a sua manhã, o vermelho suave ainda não descoberto, um novo dia, antecipando que as auroras são múltiplas, numa visão contagiante da inversão de todos os valores? $D e$ que malícias dispõe a inocência.

Neste interregno moral em que a paixão do conhecimento se está a jogar, Nietzsche surpreende no anonimato uma das aplicações de "parar de ser humano", dando vazão a uma sentença de Goethe:

Vós procurais nomear os homens

E acreditais conhecê-los pelos nomes.

Quem vê de modo mais profundo, admite de bom grado:

Que há por aí alguma coisa de anónimo.

Sprüche, HA, 1, p.309 (tradução minha)

No caso dele "viver como um pássaro que chega e segue e não tem o nome inscrito no bico! Minha alegria é saciar-me deste modo" (estamos agora no §470: No banquete de muitos). Ser anónimo é inseparável da solidão em que ele se reserva, dos solilóquios

12 Para uma variação que promete cf. M/A 456, KSA 3. 275, onde se fala de uma virtude em devir, a saber, a veracidade. 
com interlocutores que só existem entre "vier Augen" - mas que incitam à multiplicação das perspectivas -, do experimento subterrâneo que está a levar a cabo, do experimento consigo próprio e também com esta situação de intervalo, preliminar e póstuma, que mais evidente e expressiva num caso do que noutro é a situação ímpar de Nietzsche nesta obra e que deixará as suas dedadas em todas as obras que se avizinham, no banquete dos muitos. Num aforismo anterior Nietzsche dá-nos uma versão do anónimo que, por assim dizer, faz entrar em combustão tudo o que concorre para a luta contra a moral da renúncia a si próprio:

Onde estão os necessitados de espírito? [...] Mas viver sem nome ou ligeiramente ridicularizado [...] como que um espiritual médico dos pobres, ajudando esse ou aquele que tem a cabeça transtornada por opiniões, sem que perceba realmente quem o ajudou! [...] Ser como um pequeno albergue que não rejeita ninguém que esteja necessitado, mas que depois é esquecido e zombado [...] Sempre numa espécie de amor e sempre numa espécie de egoísmo e fruição de si! Possuir um domínio e, ao mesmo tempo, estar oculto e renunciar! Estar continuamente ao sol e na suavidade da graça, e no entanto saber da vizinhança dos acessos ao sublime! - Isto seria uma vida! Isto seria uma razão uma razão para viver longamente (M/A 449, KSA 3. 271-2).

Aqui, o anónimo também pode ser viver "ligeiramente ridicularizado" ou ser como um médico de gente pobre que ajudou tantos de cabeça perdida que nunca se lembrarão de quem os ajudou ou um pequeno albergue que renunciou ao "direito de admissão", também ele esquecido e até "zombado". Aqui, anonimato funde-se com uma "espécie de amor" e com uma "espécie de egoísmo e fruição de si". Aqui, "possuir um domínio" conhece irmandade com "estar oculto e renunciar": viver numa vibração de sol e graça, não ignorando que com ela se cruzam os caminhos que levam ao sublime: "Isto seria uma vida! Isto seria uma razão para viver longamente" exclama 
Molder, M. F.

Nietzsche no final, reverberando a crença de Empédocles de que os deuses vivem uma vida longa ${ }^{13}$.

7

Escreve Goethe na Máxima 1218: "Devemos cultivar as nossas forças/virtudes [Eigenschaften], não as nossas particularidades [Eigenheiten]" (tradução minha). As particularidades são de ordem caracterial, as nossas pequenas ou grandes manias, obsessões, traços psicológicos herdados ou adquiridos. As Eigenschaften respeitam às forças que vivem em nós, quer demos por elas quer não, forças que nos empurram para diante. Ai de nós se não lhes dermos vazão, se não procurarmos para elas as formas por que anseiam! Esta distinção goethiana vai directa à recusa de considerar os seres humanos como factos inteiramente consumados, que é aquilo em que as pessoas habitualmente acreditam, lembra Nietzsche no M/A 560, KSA, 3. 326. E continuando declara que houve grandes filósofos que deram cobertura a esta conviç̧ão, um preconceito, com a doutrina da "imutabilidade do carácter". Daí que ele queira agora ficar, por assim dizer, "de molho", deseje permanecer anónimo, falando apenas por enigmas - ele o amigo dos enigmas, por excelência -, cultivando as suas forças, preparando-se para se tornar no homem que é, o que exige lentidão, escuridão, solidão, deixar cair hábitos humanos, sobretudo deixar de falar, seguindo os "maus instrutores", como o mar e o vento. Daí que a obra se chame Aurora. É um lugar em incandescência contínua, povoado por ventos irisados.

Chegámos à diferença entre eu e eu. E aqui de novo, a ajuda da distinção goethiana será preciosa. Eis as passagens-chave:

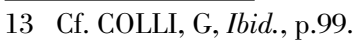


§491Outro motivo para a solidão! - A: Então quer retornar ao seu deserto? - B: Não sou veloz, tenho que esperar por mim mesmo - sempre fica tarde, até que surge a água da fonte de meu eu, e com frequência tenho de aguentar a sede por mais tempo do que a paciência me permite. Por isso vou para a solidão - a fim de não beber das cisternas de todos. Estando entre muitos, vivo como muitos e não penso como eu; após algum tempo, é como se me quisessem banir de mim mesmo e roubar-me a alma - e aborreço-me com todos e receio todos. Então o deserto me necessário para ficar novamente bom (M/A 491, KSA 3.290).

Último argumento do bravo. - "Há cobras nesses arbustos" Muito bem, vou entrar neles e matá-las. "Mas talvez você se torne vítima, e não elas a sua!" - Que importa eu! (M/A 494, KSA 3.291).

"Estando entre muitos, vivo como muitos e não penso como eu". Este eu corresponde às Eigenschaften de Goethe, aquilo que não pode ser expulso pela porta da casa de alguém pois reaparecerá pela janela, a água da sua fonte, da sua sede. Por isso ele vai para o deserto, para o lugar onde se aprende a paciência, para o lugar onde terá de esperar por si mesmo, pela fonte da água do seu eu que demora a encontrar. $\mathrm{O}$ deserto é o nome para a terapia, para a cura da doença de "beber das cisternas de todos". Quanto a "- Que importa eu!", este eu que não importa corresponde, por sua vez, às goethianas Eigenheiten, aquelas que, se foram seguidas com obediência natural, nos perdem, tornando-se em hábitos defensivos, reactivos, evitando-nos os riscos da aventura do conhecimento, a saber, sermos vítimas dos perigos que procuramos.

8

No M/A 459, KSA 3.276, A generosidade do pensador, Nietzsche estabelece um contraste, mais outro enigma bem difícil de decifrar, entre vita impemdere vero e verum impedere vitae (nem Rousseau 
nem Schopenhauer conseguiram transformar a primeira na segunda, incapazes de fazerem corresponder as suas vidas à melodia do conhecimento, no fundo é nisso que consiste dedicar a verdade à vida): o conhecimento não assentava bem no seu corpo, coisa que o pensador não pode tolerar, aceitar (se não, fechar-se-ia numa vaidade auto-benevolente). Justamente aí se acha a mais bela virtude do grande pensador: a generosidade de, como homem do conhecimento, impavidamente, muitas vezes envergonhado, muitas vezes com sublime escárnio e sorriso - fazer o sacrifício de si mesmo e da sua vida - o que é a única forma de conseguir consagrar a verdade à vida.

Dedicar a verdade à vida quer dizer, por conseguinte, fazer corresponder a vida à melodia do conhecimento, tentando fazer justiça à vida, implicando até o sacrifício da própria vida, e escuta-se uma dos grande motivos da concepção nietzchiana dos homens, o da grandeza. Um outra variação daquele contraste encontra-se no M/A 572 , KSA 3.330, num prolongamento da musicalidade que aceita que a vida se nos adianta, através da distinção entre duas espécies de pensadores, os que procuram proteger-se da vida pelo pensamento e os que só na vida encontram a tranquilidade e o silêncio que interrompe a "grande corrente do pensar e sentir, e mesmo nossos sonhos noturnos seguem essa corrente"). Nessa interrupção a vida prevalece.

Talvez o amor pelo conhecimento seja uma paixão infeliz não correspondida: dedicar a verdade à vida prova-se porque a paixão não recua diante de nenhum sacrifício a não ser a sua própria extinção. É por isso que, observa Nietzsche, tememos e odiamos um possível retorno à barbárie. "E afinal se a humanidade não perecer de uma paixão, perecerá de uma fraqueza: o que é preferível? Eis a questão principal! Queremos para ela um final em luz e fogo ou em areia?" pergunta ele no M/A 429, KSA 3.264-5 (no poema citado no final estará uma resposta). 
Uma palavra ainda sobre as ciências da sociedade (e também sobre as da fisiologia e da medicina, que tantos desenvolvimentos irão conhecer na obra futura de Nietzsche) que incorporam todas as provas por que passa a ciência da solidão, e cujos resultados desaguam sempre numa nova forma de moralidade, ou no imoralismo: cometer injustiça, ser mau, tornar infelizes os que o lêem (cf. \$404, $\$ 556$, e ainda como variações destes $§ 551, \S 242, \S 401)$. Trata-se da tragédia que os espíritos que se estão a tornar livres provocam, das consequências metodológicas da aprendizagem com os maus instrutores: parar de ser humano, mas também do fornecimento de indícios preciosos para o perspectivismo. Dito por outras palavras: uma moralidade temerária que se apoia na visão de que não existe um único método que leve ao saber: "Como todos os conquistadores, descobridores, navegadores, aventureiros, nós, investigadores, somos de uma moralidade temerária, e temos que admitir ser considerados maus no conjunto" (M/A 432, KSA 3.266).

Mas há que acrescentar um ingrediente que não pode faltar na cozinha de Aurora (e também na Gaia Ciência, por exemplo), o da zombaria que ameniza, suaviza os agrumes doa comunicação do $p a-$ rar de ser humano, pelo reforço da dissimulação como instrumento de método e de estilo, em que vemos as ciências da sociedade e da solidão agarrarem-se uma à outra como um equilibrista no seu trapézio:

Não basta. Não basta procurar uma coisa, é preciso mover ou elevar as pessoas até ela - aquele que sabe deve aprender a dizer a sua sabedoria e frequentemente de modo que soe como uma tolice (M/A 330, KSA 3.265).

E, no entanto, também não podemos ficar por aqui. Na verdade em Aurora enfiar e retirar a cabeça é um movimento sem termo: agora surpreendemos que ao tempero humorístico, eivado 
Molder, M. F.

de graciosidade, se junta um sabor mais amargo e que já não provém dos ensinamentos que vinculam entre si ciência da solidão e ciência da sociedade, antes da resistência da doença à cura, coisa que pede estudos mais avançados em fisiologia e medicina: uma atracção fatal pelo pessimismo e mesmo pelo nihilismo - e que B diz experimentar "três vezes por dia" - e que toma dois aspectos. Primeiro, o da desilusão, o do desalento, do tédio, que se abatem sobre o investigador ao descobrir no final da procura que aquilo que encontra é bem pouco, não vale assim tanto (o que mostra como é bem difícil consagrar a verdade à vida):

Num encontro. - A: Que está olhando? Há algum tempo está calado. - B: A mesma coisa antiga e nova! O desamparo de uma coisa me leva tão longe e tão profundamente dentro dela, que afinal lhe alcanço o fundo e vejo que não vale tanto. No fim de tais experiências há uma espécie de tristeza e torpor. Experimento isso em pequena escala três vezes por dia (M/A 465, KSA 3. 279).

Segundo, o daa transformação em pedra, da conversão de Don Juan no convidado de pedr (não, não é propriamente uma metamorfose, cf. M/A 327, KSA 3. 232, intitulado Uma fábula). Trata-se de um Don Juan do conhecimento: tudo para ele é objecto de caça (e não ama nada do que conhece), até que nada mais lhe falta caçar além do elemento absolutamente doloroso do conhecimento. No limite ele acabará por desejar o inferno e acaba por transformar-se no convidado de pedra, aspirando a uma ceia de conhecimento que nunca lhe será concedida: "como o beberrão que finda por tomar absinto e água-forte". Fome daquilo que resistirá à feitiçaria do poder supremo, da transformação de tudo em ouro (cf. M/A 486, KSA 3. 288, Ouro e fome). Alquimia que exige esforço, experimentação, riscos, decepções das expectativas, do género: "a este faminto nada pode saciar" ou "de que se irá apoderar aquele que transforma em ouro tudo o que toca?". Alquimista incurável, alquimia de um solitário, que corre o risco de se afundar na "mais 
perigosa aprendizagem": "Começa-se por desaprender a amar os outros e termina-se por não encontrar nada mais digno de amor em si mesmo" (M/A 401, KSA 3.252). Os efeitos desta desaprendizagem soam equivalentes ao temor de descobrir que finalmente aquilo que se encontra não vale assim tanto. Porém o "ou... ou" nem disjuntivo nem alternativo não nos deixar ficar encerrados nesses efeitos mágicos.

10

Como resistência e protecção contra o horror de "não encontrar nada mais digno de amor em si mesmo" só se conhecem as curas lentas, o exercitar das mudanças mínimas, coisas de que nos fala o $\S 462$, ao dar-nos indicações sobre como converter a ciência da solidão numa forma de aceitação da exigência da metamorfose. A ave Fénix - aquela que renasce das cinzas - mostra ao poeta um rolo em chamas, quase carbonizado e diz-lhe (M/A 568, KSA 3.32930): «Não te apavores, é a tua obra, não tem o espírito da época nem é contra ela, logo tem de ser queimada - é um bom sinal - há muitas espécies de auroras» (o que tem a ver com ou... ou, e com a diferença entre eu e eu, mas também com a lentidão, com as pequenas doses, isto é, com a recusa da moral da renúncia a si próprio).

Esta ave é da estirpe do poeta - e aqui poeta ou filósofo vão dar ao mesmo, o que interessa é esse alguém que não está com a sua época nem contra ela, alguém que não quer renunciar a si próprio -, a ave das metamorfoses. Essa ave virá ter com o poeta de cada vez - prenúncio da visão do eterno retorno. As auroras são as interrupções, as fendas irisadas, parentes daquele ramo da árvore da vida que, em rigor, não é uma emanação, mas um intervalo entre a sabedoria e o entendimento, o intervalo onde o caos faz a sua entrada, o intervalo do conhecimento. Fénix, a ave que renasce das cinzas, é uma das espécies de auroras, da metamorfose da noite em dia, outras poderão ser acrescentadas: largar a pele 
como a serpente (§573): se não mudar de pele, a serpente perece, o mesmo acontece com os espíritos que sofrem a petrificação letal, isto é, aqueles que não mudam de opinião.

Porém a melhor metamorfose (verdadeiramente dionisíaca $\mathrm{cf}$. Crepúsculo dos ídolos), que vai muito além de renascer das cinzas, muito além de mudar de pele, é a da gravidez "Cresce aqui algo maior do que o que somos" diz ele no M/A 573, KSA 3.330-1: a sua esperança mais secreta. Engravidar (não dar à luz, mas engravidar, ficar cheio de vida, alimentar a vida, dedicar a verdade à vida), é nesta consagração que devemos viver: seja um acto seja um pensamento, não há outro vínculo a não ser o da gravidez. "eis o autêntico egoísmo idealista: cuidar sempre, velar e manter sossegada a alma, para que a nossa fecundidade tenha um belo final". A excentricidade deste pensador pede clemência junto daqueles que o julgam e julgarão, que o condenam e condenarão, exultação em que nenhum tribunal tem mão, em que nenhum carrasco porá a mão:

"A gravidez torna as pessoas excêntricas, pois seja e não fiquemos atrás da justiça profana que não permite nem ao juiz nem ao carrasco tocarem numa mulher grávida!"

Finalmente (ou ainda, como se quiser), e contrariando palavras que dissemos ao enfiar a cabeça no aforismo do Don Juan, poderíamos recorrer a um tornar-se pedra que é também metamorfose, a mais lenta, a mais cósmica das metamorfoses, a mais difícil, depois dela o calar será outro, para além de toda a diferença, para além de todo o esforço, para além das instruções do mar e da noite ou seguindo-as até ao fim?: Como nos devemos petrificar. - Tornar-se duro lentamente, lentamente como uma pedra preciosa - e, por fim, jazer silencioso, para alegria da eternidade (M/A 541, KSA 3.309).

É observável o derramamento de Aurora nos anos seguintes em particular na Gaia Ciência, decantação fértil, variações instrutivas, 
outros tantos patamares de vir a tornar-se naquilo que se é (cuja fonte parece ser um verso das Odes Píticas de Píndaro) Vimos já alguns exemplos flagrantes - que como pedras preciosas se encaixam no seu encastoamento - no que se refere à relação entre visão e nome, visão e baptismo, que dão o timbre à concepção de originalidade em Nietzsche. Lembremos ainda os efeitos de longuíssimo alcance - isto é, atravessam Gaia Ciência e vão desaguar em Ecce homo - de "sermos experimentos", o que no FW/GC 319, KSA 3.550-1 se traduz de forma crua como: "somos cobaias". E continuando neste percurso da metamorfose que acabará por se suspender naquilo que ele é, veja-se o FW/GC 324, KSA 3.552-3, onde a vida é vista como uma experiência daquele que busca o conhecimento ou dito de outro modo, a vida como meio de conhecimento, intimamente inseparável da interrogação que em Aurora se faz sobre diferença entre dedicar a vida à verdade (como esta nos parece a escolha óbvia, a acertada, a que exalta o espírito de sacrifício, o ideal, a coragem) e dedicar a verdade à vida (aqui, ficamos baralhados, e é esta a via que Nietzsche escolhe ou?). E ainda, e como precipitado daquela experiência e sua aplicação certeira, conseguir infligir-se dor e não perecer, tal como nos instrui o FW/GC 325, KSA 3.553. Tudo depende, veja-se o FW/GC 370, KSA 3.619-22, de a nossa exaustão, o nosso sofrimento, terem origem na fome ou na abundância (também segurámos esta lançadeira em Aurora).

Mas aquele derramamento é particularmente fértil, como o de um rio benigno, no que se refere à descoberta do seu elemento, à decisão de beber do seu poço, ao seu acto destrutivo e lustral: ele é chama, fulgor, é isso que ele sabe dele, o não-saciado, é essa a raça a que pertence: ecce homo! Tudo aquilo em que toca brilha em fogo, tudo aquilo que larga transforma-se em carvão: prova provada de que ele é uma chama, fogo e fulgor, prova provada do destino que lhe cabe enquanto tal: fazer arder aquilo em que toca transformando em carvão aquilo em que deixa cair (uma variação de ouro e fome). É esse o seu retrato num dos poemas que fazem parte do "Prelúdio em rimas alemãs" que se segue ao Prefácio da $2^{a}$ edição 
de A Gaia Ciência e cujo nome dará alguns anos mais tarde o título à sua derradeira obra. Ei-lo:

Ecce homo

Ja! Ich weiss, woher ich stamme!

Ungesättigt gleich der Flamme

Glühe und verzehr' ich mich.

Licht wird Alles, was ich fasse,

Kohle Alles, was ich lasse:

Flamme bin ich sicherlich

Die fröhliche Wissenschaft, „Scherz, List und Ruhe“

(Vorspiel in deutschem Reimen)

Abstract: Starting from the thorough analysis of some parts of Daybreak, this work aims to demonstrate how Nietzsche reconfigures the understanding of human being from a new basis.

Keywords: Nietzsche - Daybreak - human - life - moral

\section{referências bibliográficas}

ANDLER, C. Nietzsche. Sa vie et sa pensée. Paris: Galllimard, 1958, 3v.

ANTONIONI, M. Fare un film è per me vivere. Scritti sul cinema. Veneza: Marsilio Editore, 1994.

BAUDELAIRE. C. Le Spleen de Paris. In: Oeuvres Completes. Paris: Robert Lafont, Paris, 1980.

COLLI, G. Dopo Nietzsche. Milão: 4․ Ed. Milão: Adelphi Edzioni, 1988.

D'IORIO, P. Le voyage de Nietzsche à Sorrento. Génese de la philosophie del'esprit libre. Paris : CNRS Éditions, 2012.

GOETHE, J.W. v. Werke. Hamburg: Hamburger Ausgabe, ed. Erich Trunz, Christian Wegner Verlag, Hamburg, 1948-1966, 14v.; Deutscher Taschenbuch Verlag, C.H. Beck, München, 1982.

NIETZSCHE, F. Sämtliche Werke. Kritische Studienausgabe. München/Berlin: DTV/ Wlater de Grutyer, 1980, 15v. (Ed. Giorgio Colli/Mazzino Montinari). 
. Aurora. Trad. Paulo César de Sousa. São Paulo: Companhia das Letras, 2008.

- A Gaia Ciência. In: Obras Escolhidas de Friedrich Nietzsche. Trad. Maria

Helena Rodrigues de Carvalho, Maria Leopoldina Almeida e Maria Encarnação Casquinho. Lisboa: Relógio d'Água, 1998, v.13.

. O Anticristo, Ecce Homo e Nietzsche contra Wagner. In: Obras Escolhidas de Friedrich Nietzsche. Trad. Paulo Osório de Castro. Lisboa: Relógio d’Água, 2000, v.7.

. Para Além do Bem e do Mal. In: Obras Escolhidas de Friedrich Nietzsche. Trad. Carlos Morujão. Relógio d'Água: Lisboa, 1999, v.5.

L'Epopée de Gilgames. Le grand homme qui ne voulait pas mourir. Trad. Jean Bottéro. Paris : Gallimard, 1992.

Artigo recebido em 20/09/2012.

Artigo aceito para publicação 12/11/2012. 